\title{
Production and Characterization of Tissue Cultures of Four Crocus Species from the Carpathian Basin
}

\author{
Csongor FreytaG $^{1}$, SÁndor Attila Pabar ${ }^{1 *}$, Zita Demeter ${ }^{1}$, ÁdÁm Simon $^{1}$, \\ Anna ResetáR ${ }^{1}$, Attilla MolnáR V. ${ }^{*}{ }^{*}$, Gábor Sramkó ${ }^{1,2}$ and Csaba Máthé ${ }^{1 * *}$ \\ ${ }^{1}$ University of Debrecen, Faculty of Science and Technology, Department of Botany, \\ Egyetem ter 1, H-4032, Debrecen, Hungary \\ ${ }^{2}$ MTA-DE "Lendület” Evolutionary Phylogenomics Research Group, Egyetem ter 1, \\ H-4032, Debrecen, Hungary
}

Received April 21, 2017; revision accepted July 10, 2017

\begin{abstract}
We aimed to produce tissue cultures and plant regeneration from endangered Crocus species: C. scepusiensis, C. tommasinianus, C. vittatus ("Verni" series of the genus) and C. banaticus. For initiation of cultures we used a plant growth regulator (PGR) combination used for in vitro culture of saffron and its relatives: $10 \mathrm{mg} \mathrm{L}^{-1}$ $\alpha$-naphthaleneacetic acid (NAA) and $1 \mathrm{mg} \mathrm{L}^{-1}$ 6-benzyladenine (BA). Shoot tips of young seedlings (C. scepusiensis) and corms (for the rest of species) were used as explants. C. scepusiensis explants developed into organogenic calli. On media with decreased NAA and with or without increased BA concentration, calli produced stigma-like structures and/or shoots and whole plants. In the other species, callus initiation medium induced callus formation with abundant somatic embryos. In C. tommasinianus, embryos developed shoots when auxin content of medium was decreased. In C. banaticus, a decrease of auxin with or without an increase in cytokinin content led to shoot or whole plant regeneration, as in C. scepusiensis. In the case of $C$. vittatus and C. banaticus, initiation and/or maintenance of cultures on indole-3-butyric acid (IBA) and increased sucrose concentration stimulated whole plant regeneration and in vitro cormlet development. C. scepusiensis and the rest of cultures (organogenic vs. embryogenic) differed at the biochemical level: C. scepusiensis cultures had higher (yet still low) enzymatic antioxidant (catalase, peroxidase) activities. With respect to catalase isoenzyme patterns, C. banaticus was different from the rest of cultures, demonstrating its distinct taxonomical position. Besides germplasm preservation use of the present cultures, they have a potential biotechnological value.
\end{abstract}

Keywords: Crocus, Carpathian Basin, organogenesis, embryogenesis, plant regeneration, antioxidant enzymes

\section{INTRODUCTION}

Saffron (Crocus sativus L., Iridaceae) is a wellknown crop species, cultivated mainly for its dried stigmas, the most expensive spice that contains apocarotenoids with antioxidant properties (Gantait and Vahedi, 2015). The genus Crocus includes a considerable number of wild-growing species, several of them being endangered, thus their conservation is important (Fernández et al., 2011). The species involved in our study were: (i) species taxonomically belonging to the "Verni" series: C. scepusiensis Borbás Ex Kulczyński endemic to Slovakia and Southern Poland, the Northern Carpathians, C. tommasinianus Herbert native to Hungary and the Balkans, C. vittatus Schlosser
\& Vukotinović native to Croatia and Hungary (C. heuffelianus Herbert, another member of this taxonomical series, has already been successfully cultured in vitro in our laboratory, see Demeter et al., 2010); (ii) the taxonomically distinct C. banaticus Gay, native to the Banat (Romania, Serbia), as well as Romanian and Ukrainian regions of the Carpathian Basin. C. tommasinianus and C. vittatus are red list species in Hungary (Király, 2007), while C. banaticus is protected in Romania (Pătroescu and Rozyłowicz, 2000).

Tissue culture of saffron and its relatives is of double importance: (i) concerning C. sativus, it has biotechnological value mainly in the search for alternative to traditional breeding methods of producing biologically active compounds (Gantait

\footnotetext{
* these two authors contributed equally to the present work

${ }^{* *}$ Corresponding author, email: mathe.csaba@science.unideb.hu
} 
and Vahedi, 2015); (ii) germplasm preservation involves not only different genotypes of saffron, but also of its wild relatives. The genetic diversity of saffron is decreasing, partly because, being a triploid hybrid, it does not reproduce sexually (Fernández et al., 2011). Thus, tissue culture may offer a good method to preserve valued genotypes. As for wildgrowing species, their preservation via tissue culture is important not only for conservation purposes, but also in the search for novel biologically active compounds (Demeter et al., 2010).

There is a vast literature concerning tissue culture methods of saffron. These include plant regeneration from both floral explants and vegetative tissues via callus cultures, as well as direct micropropagation from corm explants by excluding the callus stage or protoplast culture (see Gantait and Vahedi, 2015 for a comprehensive review). As for wild relatives, we can find elegant plant regeneration methods for $C$. cancellatus, C. pallasii, etc. (Karamian and Ebrahimzadeh, 2001; Karamian, 2007). For species belonging to the Verni series of Crocus, there is only a limited number of tissue culture studies. Demeter et al. (2010) established an efficient plant regeneration method from embryogenic calli of $C$. heuffelianus. Sivanesan et al. $(2012,2014)$ reported efficient somatic embryo production and shoot regeneration from corm explants of C. vernus. Callus cultures of C. scepusiensis, C. tommasinianus and C. banaticus have been deposited in the tissue culture collection of the University of Debrecen (UD), Department of Botany, Hungary (Máthé et al., 2012), but to date, there is no international literature on plant regeneration from tissue cultures of the species used in the present study. Thus, the aim of this work was to: (i) establish and maintain tissue cultures of four wild-growing Crocus species for germplasm preservation and future experiments (not included in this paper) on their bioactive compound content; (ii) search for biochemical markers related to the type of tissue culture morphogenesis. Since antioxidant enzyme activities proved to be suitable markers (see, e.g., Blazquez et al., 2009), we chose the study of catalase (CAT) and peroxidase (POD) isoenzyme patterns on activity gels.

\section{MATERIALS AND METHODS}

\section{PLANT MATERIAL}

The location of plants serving as sources for tissue culture was as follows: C. scepusiensis - Vernár, central Slovakia; C. tommasinianus - Gyulaj, southwestern Hungary; C. vittatus - Pápasalamon, western Hungary; C. banaticus - Sovata, eastern Transsylvania, Romania. Corms of each species were collected in 2007 as part of a Crocus genebank collection program directed by the European Commission and called AGRI GEN RES 18 "CROCUSBANK" action (Fernández et al., 2011) that allowed the creation of a large collection of saffron crocus and its relatives. Two or three corms of the species involved in this study were further cultivated in the Botanical Garden of UD. In 2012, when shoots emerged, leaf and corm explants were sampled for further tissue culture. For C. scepusiensis, shoot tips from young seedlings (seeds produced in the Botanical Garden of UD and then surface sterilized) were also used for this purpose.

\section{TISSUE CULTURE PROCEDURES AND CONDITIONS}

Explants were surface sterilized by rinsing with $10 \%(\mathrm{v} / \mathrm{v})$ Domestos bleach twice, followed by three consecutive washes with sterile water for $5 \mathrm{~min}$. Sterile tissues were placed on plastic petri dishes (Sarstedt, Nümbrecht, Germany) with full-strength MS medium (Murashige and Skoog, 1962) modified in that it was supplemented with Gamborg's vitamins (Gamborg et al., 1968). Basal medium was then supplemented with 2 or $5 \%(\mathrm{w} / \mathrm{v})$ sucrose (Molar, Halásztelek, Hungary) and solidified with $0.8 \%$ (w/v) Difco-agar (Difco, Lawrence, KS, USA). The following plant growth regulators (PGR) were used: $\alpha$-naphthaleneacetic acid (NAA, Duchefa Biochemie, Haarlem, The Netherlands), indole-3-butyric acid (IBA, Sigma-Aldrich, St. Louis, Mo., USA) as auxins and 6-benzylaminopurine (BA, Duchefa Biochemie). Their concentrations depended on the culture condition tested (see Results section), but in principle they were: $0.5-10 \mathrm{mg} \mathrm{L}^{-1}(2.68-53.7 \mu \mathrm{M})$ NAA, $1 \mathrm{mg} \mathrm{L}^{-1}(4.9 \mu \mathrm{M}) \mathrm{IBA}$ and $1-5 \mathrm{mg} \mathrm{L}^{-1}(4.44-22.2 \mu \mathrm{M})$ BA. The physical conditions of the culture were as follows: continuous dim light of $5 \mu \mathrm{mol} \mathrm{m}{ }^{-2} \mathrm{sec}^{-1}$, $22 \pm 3^{\circ} \mathrm{C}$. The age of cultures is specified in the Results section, Table 1.

Several tissue cultures were subject to histological analysis. In this case, calli were fixed with $4 \%(\mathrm{v} / \mathrm{v})$ formaldehyde (Reanal, Budapest, Hungary) and then cryosectioned with a Leica Jung Histoslide 2000 microtome (Leica, Nussloch, Germany). 20-25 $\mu \mathrm{m}$ thick sections were examined by using the bright-field and fluorescence facilities of an Olympus Provis AX-70 (Olympus, Tokyo, Japan) fluorescence microscope. Autofluorescence of cell walls was detected by excitation at $320-360 \mathrm{~nm}$.

\section{IN-GEL ASSAY OF CAT AND POD ACTIVITIES}

Typically, $45 \mathrm{~d}$ old callus cultures grown on $5 \mathrm{mg} \mathrm{L}^{-1}$ NAA and $1 \mathrm{mg} \mathrm{L}^{-1} \mathrm{BA}$ were used for enzyme activity assays, except when specified (see Results section). Calli were extracted at a 1:2 ratio (callus fresh weight : buffer volume) at $4^{\circ} \mathrm{C}$ with 
TABLE 1. Main characteristics of Crocus tissue cultures involved in this study. The best culture conditions for plant regeneration are indicated in bold for each species.

\begin{tabular}{|c|c|c|c|c|}
\hline $\begin{array}{l}\text { PGR content, induction } \\
\text { medium }^{\mathrm{a}}\end{array}$ & $\begin{array}{c}\text { PGR content, } \\
\text { maintenance/ } \\
\text { subculturing medium }{ }^{\mathrm{a}}\end{array}$ & $\begin{array}{l}\text { Culture age } \\
\text { (days) }\end{array}$ & Main features of culture & $\begin{array}{c}\text { No. of whole } \\
\text { plants or shoots/ } \\
\text { callus }^{b}\end{array}$ \\
\hline \multicolumn{5}{|c|}{ 1. C. scepusiensis shoot tip explants } \\
\hline $\mathrm{NAA}(10)+\mathrm{BA}(1)$ & $\mathrm{NAA}(10)+\mathrm{BA}(1)$ & $20-50$ & organogenic callus & 0 \\
\hline $\mathrm{NAA}(10)+\mathrm{BA}(1)$ & $\mathrm{NAA}(5)+\mathrm{BA}(1)$ & $20-30$ & $\begin{array}{l}\text { organogenic callus, } \mathrm{SLS}^{\mathrm{c}} \text {, sporadic shoot } \\
\text { formation }\end{array}$ & $0.2 \pm 0.2$ \\
\hline $\mathrm{NAA}(10)+\mathrm{BA}(1)$ & $\mathbf{N A A}(5)+\mathbf{B A}(5)$ & 20-30 & whole plant regeneration ${ }^{d}$ & $6 \pm 2.44$ \\
\hline $\mathrm{NAA}(10)+\mathrm{BA}(1)$ & $\mathrm{NAA}(2)+\mathrm{BA}(4)$ & $20-60$ & SLS & 0 \\
\hline \multicolumn{5}{|c|}{ 2. C. tommasinianus corm explants } \\
\hline $\mathrm{NAA}(10)+\mathrm{BA}(1)$ & $\mathrm{NAA}(10)+\mathrm{BA}(1)$ & 30 & $\begin{array}{l}\text { embryogenic callus, sporadic shoot } \\
\text { formation }\end{array}$ & $1.09 \pm 0.32$ \\
\hline $\mathrm{NAA}(10)+\mathrm{BA}(1)$ & $\mathrm{NAA}(5)+\mathrm{BA}(1)$ & $25-50$ & embryogenic callus, shoot regeneration & $2.36 \pm 0.32$ \\
\hline $\mathrm{NAA}(10)+\mathrm{BA}(1)$ & $\operatorname{IBA}(1)^{\mathrm{e}}$ & $35-50$ & $\begin{array}{l}\text { embryogenic callus, whole plant } \\
\text { regeneration }\end{array}$ & $8.28 \pm 2.31$ \\
\hline \multicolumn{5}{|c|}{ 3. C. vittatus, corm explants } \\
\hline $\mathrm{NAA}(10)+\mathrm{BA}(1)$ & $\mathrm{NAA}(10)+\mathrm{BA}(1)$ & $30-40$ & $\begin{array}{l}\text { embryogenic callus, sporadic shoot } \\
\text { regeneration }\end{array}$ & $0.6 \pm 0.2$ \\
\hline $\operatorname{IBA}(1)^{\mathrm{e}}$ & $\operatorname{IBA}(1)^{\mathrm{e}}$ & $40-90$ & $\begin{array}{l}\text { no callus involved; corm explants } \\
\text { developed cormlets, then whole plants }\end{array}$ & $\begin{array}{c}\text { no callus; } 1 \text { corm } \\
\text { explant produced } \\
1.71 \pm 0.42 \\
\text { cormlets with } \\
\text { plants }\end{array}$ \\
\hline \multicolumn{5}{|c|}{ 4. C. banaticus, corm explants } \\
\hline $\mathrm{NAA}(10)+\mathrm{BA}(1)$ & $\mathrm{NAA}(10)+\mathrm{BA}(1)$ & $20-60$ & embryogenic callus, shoot regeneration & $1.71 \pm 0.91$ \\
\hline $\mathrm{NAA}(10)+\mathrm{BA}(1)$ & $\mathrm{NAA}(5)+\mathrm{BA}(1)$ & $25-50$ & $\begin{array}{l}\text { embryogenic callus, sporadic shoot } \\
\text { regeneration }\end{array}$ & $1.11 \pm 0.69$ \\
\hline $\mathrm{NAA}(10)+\mathrm{BA}(1)$ & $\mathrm{NAA}(5)+\mathrm{BA}(5)$ & $25-50$ & embryogenic callus, shoot regeneration & $1.95 \pm 0.64$ \\
\hline $\mathrm{NAA}(10)+\mathrm{BA}(1)$ & $\mathrm{NAA}(0.5)+\mathrm{BA}(2)$ & $40-60$ & $\begin{array}{l}\text { embryogenic callus, plant regeneration } \\
\text { with cormlets }\end{array}$ & $8.0 \pm 0.77$ \\
\hline $\mathrm{NAA}(10)+\mathrm{BA}(1)$ & $\operatorname{IBA}(1)^{\mathrm{e}}$ & $30-90$ & $\begin{array}{l}\text { embryogenic callus, plant regeneration } \\
\text { with cormlets }\end{array}$ & $2.16 \pm 0.79$ \\
\hline
\end{tabular}

${ }^{\mathrm{a}}$ concentrations in $\mathrm{mg} \mathrm{L}{ }^{-1}$ are given in brackets; ${ }^{\mathrm{b}}$ mean $\pm \mathrm{SE}$ values are given; ${ }^{\mathrm{S}} \mathrm{SLS}$ - stigma-like structures; ${ }^{\mathrm{d}}$ for whole plant regeneration, both root and shoot development occurred; ${ }^{\mathrm{e}}$ culture medium contained $5 \%(\mathrm{w} / \mathrm{v})$ sucrose.

a buffer containing $100 \mathrm{mM} \mathrm{KH} \mathrm{PO}_{4} / \mathrm{K}_{2} \mathrm{HPO}_{4}$ (VWR International Ltd., Debrecen, Hungary), $\mathrm{pH} 7.2$, $8 \mathrm{mM} \mathrm{MgCl}$ (Reanal, Budapest, Hungary). After $2 \times 10$ min centrifugations with a Heraeus Biofuge, protein content of supernatants was determined by the Bradford (1976) method. This was necessary to ensure that protein amounts were sufficient for detecting enzyme activities. Extracts containing equal amounts (FW) of plant samples were loaded onto native $7.5 \%$ polyacrylamide gels. POD activity gels (native polyacrylamide gels) were prepared and assayed using a pyrogallol staining method as described previously (Demeter et al., 2014; Garda et al., 2016). In-gel analysis of CAT activity was performed according to the protocol described by Weidert and Cullen, 2010: native gels were incubated in $0.03 \% \mathrm{H}_{2} \mathrm{O}_{2}$, washed and incubated in $0.76 \mathrm{mM} \mathrm{K}_{3}\left[\mathrm{Fe}(\mathrm{CN})_{6}\right]$ and $1.5 \mathrm{mM} \mathrm{FeCl}_{3}$. 
Enzyme activities (band areas) were quantified with the aid of GelAnalyzer2010® software.

All tissue culture and enzyme assay experiments were repeated at least five times.

\section{RESULTS}

\section{TISSUE CULTURE AND PLANT REGENERATION}

Culture conditions and morphogenetic responses are summarized in Table 1. Surface sterilized explants were transferred to a culture medium containing $10 \mathrm{mg} \mathrm{L}^{-1} \mathrm{NAA}$ and $1 \mathrm{mg} \mathrm{L}^{-1} \mathrm{BA}$ as for the initiation of tissue cultures in C. heuffelianus (Demeter et al., 2010). As for C. scepusiensis, shoot tip explants derived from $7 \mathrm{~d}$ old seedlings were the most suitable for callus induction, as compared to corm and leaf explants. Callus formation was characteristic after 25-30 days of explant culture and after 50-60 days these calli were ready for subculture/maintenance (Fig. 1a). This was characteristic of all cultures including the other Crocus species presented in this study (see below). When NAA concentration was reduced (5 mg L $\mathrm{m}^{-1} \mathrm{NAA}$ and $1 \mathrm{mg} \mathrm{L}^{-1} \mathrm{BA}$ ) or cytokinin/ auxin ratio was reverted and higher cytokinin concentration was used, calli produced stigmalike structures (SLS, Figs. 1b, c). For the former PGR composition, SLS formation was accompanied by shoot development (Fig. 1c). On culture media containing $5 \mathrm{mg} \mathrm{L}^{-1} \mathrm{NAA}$ and $5 \mathrm{mg} \mathrm{L}^{-1} \mathrm{BA}$, no SLS formation was detected, but whole plants (structures containing both well-developed shoots and roots) regenerated efficiently (Fig.1d).

As for the rest of species belonging to the "Verni" series (C. tommasinianus and C. vittatus) and $C$. banaticus, corm explants were the most suitable for the efficient production of tissue cultures. On $10 \mathrm{mg} \mathrm{L}^{-1} \mathrm{NAA}$ and $1 \mathrm{mg} \mathrm{L}^{-1} \mathrm{BA}$ (initiation and maintenance medium) they all produced visibly morphogenic calli (Figs. 1e, i, k). In C. tommasinianus, when NAA content of culture medium was reduced, shoot regeneration was stimulated and somatic embryo development became macroscopically visible (Figs. 1f, g; Table 1). When calli were shifted from initiation and maintenance medium to a medium containing $1 \mathrm{mg} \mathrm{L}^{-1}$ IBA and high (5\%) sucrose concentration, embryogenic calli efficiently produced whole plants (Fig. 1h). In C. vittatus, initiation and maintenance medium sporadically induced shoot formation, while the calli were embryogenic (Fig. 1i). If corm explants were initiated and maintained on modified MS medium with $1 \mathrm{mg} \mathrm{L}^{-1}$ IBA and $5 \%$ sucrose, efficient whole plant regeneration and cormlet formation occurred (Fig. 1j). In the case of $C$. banaticus, initiation and maintenance medium ( $10 \mathrm{mg} \mathrm{L}^{-1} \mathrm{NAA}$ and $1 \mathrm{mg} \mathrm{L}^{-1} \mathrm{BA}$ ) did induce somatic embryo formation that developed into shoots with young cormlets (Fig. 1k). Similar results were obtained, when auxin content was decreased, and cytokinin content increased in the medium (Fig. 11, Table 1). Reverting the auxin/ cytokinin ratio $\left(0.5 \mathrm{mg} \mathrm{L}^{-1} \mathrm{NAA}\right.$ and $\left.2 \mathrm{mg} \mathrm{L}^{-1} \mathrm{BA}\right)$ led to efficient whole plant regeneration and these plants developed cormlets (Fig. $1 \mathrm{~m}$ ).

For C. scepusiensis cultures, autofluorescence studies showed that these calli are capable of tracheary element differentiation (Fig. 2a). Histological analysis confirmed differentiation of SLS showing typical stigma and stylar structures including formation of stylar canals (Figs. 2b-d). Microscopical analysis of callus structures capable of shoot or whole plant regeneration showed that first shoot primordia, and not somatic embryos, will develop (Figs. 2e, f), and in the case of whole plant development, this is followed by rooting. Thus, C. scepusiensis calli are organogenic. Histological analysis confirmed the formation of typical somatic embryos in C. banaticus cultures. Young embryogenic calli had early stage somatic embryos on their surface (Fig. 2g).

Acclimation experiments for tissue culture derived regenerants started. Cormlets of $C$. vittatus and $C$. banaticus regenerated in vitro were planted into pots with normal soil with medium nutrient content and $\mathrm{pH}$ 6-7 and grown under a $12 \mathrm{~h}$ photoperiod with temperature conditions of $15 \pm$ $2^{\circ} \mathrm{C}$ during the illumination and $6 \pm 1{ }^{\circ} \mathrm{C}$ during the dark period. C. vittatus cormlets show the best results with frequent formation of viable shoots (data not shown).

\section{CAT AND POD ACTIVITIES}

To avoid PGR dependent variation of antioxidant activities, we produced enzyme extracts of the Crocus cultures studied, from calli grown under similar conditions and of similar age $\left(5 \mathrm{mg} \mathrm{L}^{-1}\right.$ NAA and $1 \mathrm{mg} \mathrm{L}^{-1} \mathrm{BA}, 45 \mathrm{~d}$ old cultures). These conditions were suitable for large callus biomass production for C. scepusiensis, C. tommasinianus and $C$. banaticus. C. vittatus was an exception, where we had to change the conditions, because the former PGR content and age did not allow to produce enough biomass to prepare sufficient amounts of protein extracts (for this species, $65 \mathrm{~d}$ old cultures grown on $10 \mathrm{mg} \mathrm{L}^{-1} \mathrm{NAA}$ and $1 \mathrm{mg} \mathrm{L}^{-1}$ BA were used). All cultures showed characteristic isoenzyme activity patterns. For both CAT and POD, quantitative analysis showed low enzyme activities, as compared to positive controls, with the highest activities in C. scepusiensis (Fig. 3). As for CAT, different cultures showed different isoenzyme activity patterns (Fig. 3a). Band 1 was detected 

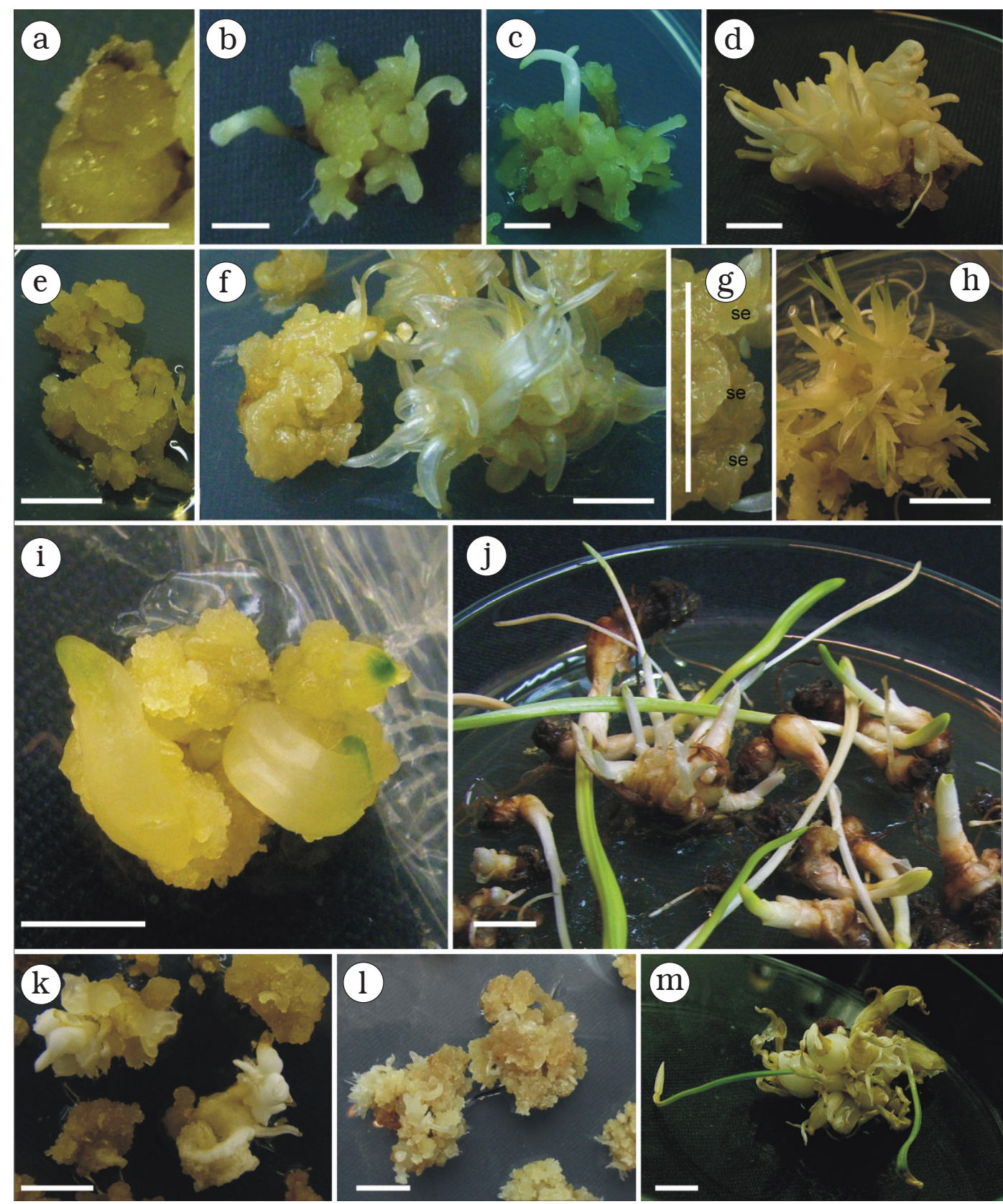

Fig. 1. (a-d) Tissue cultures of C. scepusiensis. (a) Induction of organogenic callus formation, 60-day-old culture on MS medium with Gamborg's vitamins, $10 \mathrm{mg} \mathrm{L}^{-1} \mathrm{NAA}$ and $1 \mathrm{mg} \mathrm{L}^{-1} \mathrm{BA}$. (b) Formation of stigma-like structures (SLSs) on organogenic calli, 60-day-old culture in the presence of $4 \mathrm{mg} \mathrm{L}^{-1} \mathrm{BA}$ and $2 \mathrm{mg} \mathrm{L}^{-1} \mathrm{NAA}$. (c, d) Organogenic calli with shoot development together with SLS formation on $5 \mathrm{mg} \mathrm{L}^{-1} \mathrm{NAA}$ and $1 \mathrm{mg} \mathrm{L}^{-1} \mathrm{BA}$ (c) or intensive plant development in the presence of $5 \mathrm{mg} \mathrm{L}^{-1} \mathrm{NAA}$ and $5 \mathrm{mg} \mathrm{L}^{-1} \mathrm{BA}(\mathrm{d}), 40$-day-old cultures. (e-h) Tissue cultures of C. tommasinianus, (e) 29-dayold embryogenic callus of $C$. tommasinianus on a callus initiation and maintenance medium containing 10 mg $\mathrm{L}^{-1} \mathrm{NAA}^{-1}$ and $1 \mathrm{mg} \mathrm{L}^{-1} \mathrm{BA}$. (f) 43-day-old culture after transfer of calli from initiation medium to a culture medium with $5 \mathrm{mg} \mathrm{L}^{-1}$ NAA plus $1 \mathrm{mg} \mathrm{L}^{-1} \mathrm{BA}$. Shoot regeneration can be observed. (g) Detail from the culture presented on (f), showing somatic embryos (se). (h) Mass plant regeneration in the presence of $1 \mathrm{mg} \mathrm{L}^{-1}$ IBA and 5\% (w/v) sucrose, 50-day-old culture. $(\mathbf{i}, \mathbf{j})$ Tissue cultures of $C$. vittatus. (i) 42-day-old culture of $C$. vittatus grown in the presence of $10 \mathrm{mg}^{-1} \mathrm{NAA}$ and $1 \mathrm{mg} \mathrm{L}^{-1} \mathrm{BA}$. (j) High-frequency of (cormlet containing) plant regeneration in 90-day-old cultures that were transferred to $1 \mathrm{mg} \mathrm{L}^{-1}$ IBA and $5 \%(\mathrm{w} / \mathrm{v})$ sucrose. $(\mathbf{k}-\mathbf{m})$ Tissue cultures of $C$. banaticus. (k) 55-day-old culture of $C$. banaticus grown on $10 \mathrm{mg} \mathrm{L}^{-1} \mathrm{NAA}$ and $1 \mathrm{mg} \mathrm{L}^{-1} \mathrm{BA}$, initiation of shoot regeneration. (1) 30-day-old embryogenic calli grown on $5 \mathrm{mg} \mathrm{L} \mathrm{L}^{-1}$ NAA and $5 \mathrm{mg} \mathrm{L}^{-1} \mathrm{BA}$. (m) Regeneration of whole plants with cormlets, 60-day-old culture grown on $2 \mathrm{mg} \mathrm{L}^{-1} \mathrm{BA}^{\mathrm{m}}$ and $0.5 \mathrm{mg} \mathrm{L}^{-1} \mathrm{NAA}$. Scalebars: $5 \mathrm{~mm}$. 

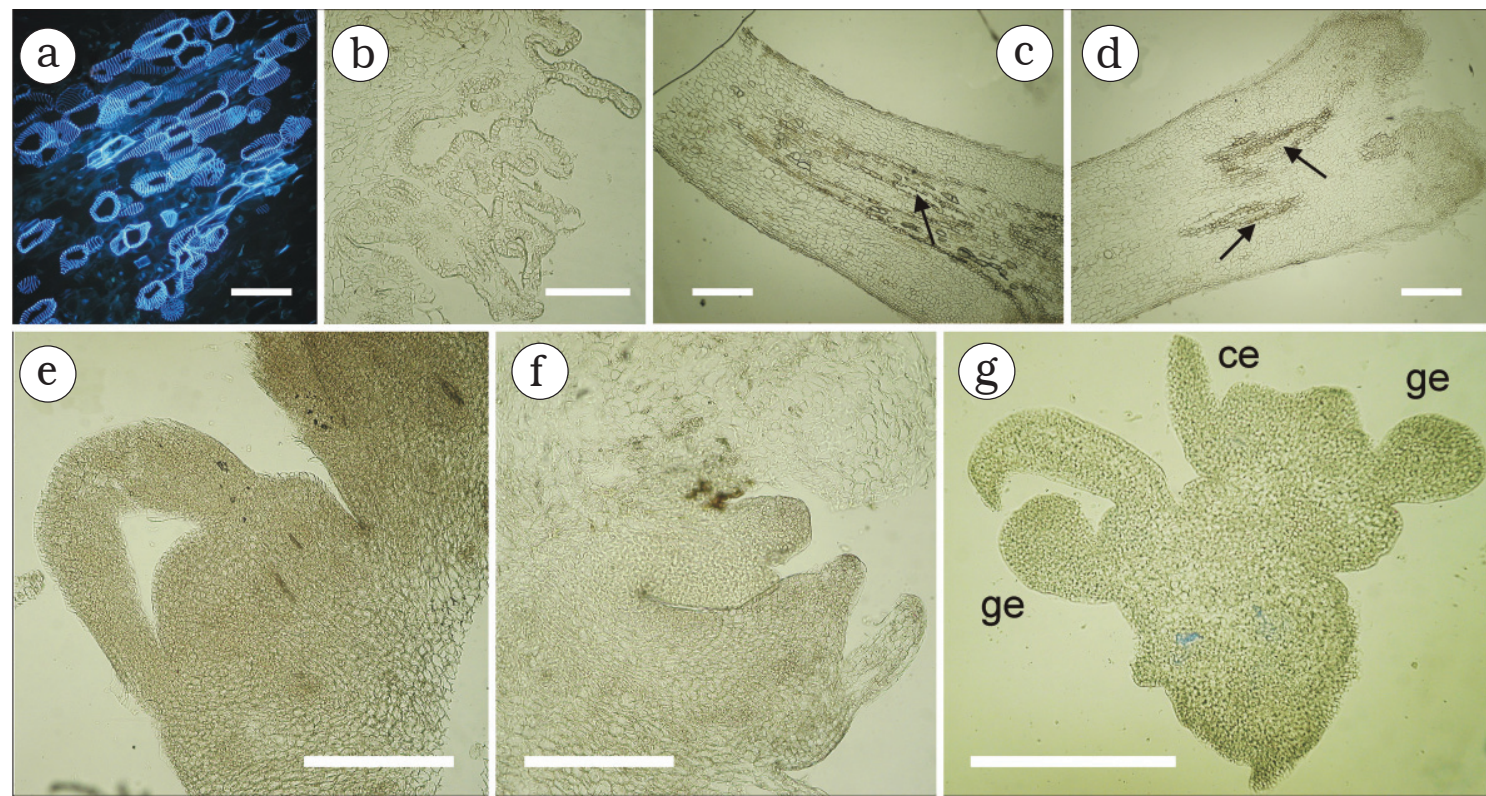

Fig. 2. Histological analysis of $C$. scepusiensis (a-f) and C. banaticus (g) tissue cultures. (a) Autofluorescence of $C$. scepusiensis tracheary elements differentiated within calli in the presence of $2 \mathrm{mg} \mathrm{L}^{-1} \mathrm{NAA}$ and $2 \mathrm{mg} \mathrm{L}^{-1} \mathrm{BA}$, 13-day-old culture. (b-d) Formation of stigma-like structures (SLSs) on organogenic calli. (b) 30-day-old cultures in the presence of $5 \mathrm{mg} \mathrm{L}^{-1} \mathrm{NAA}$ plus $1 \mathrm{mg} \mathrm{L}^{-1} \mathrm{BA}$. (c, d) Longitudinal histological sections showing SLSs formed on $4 \mathrm{mg} \mathrm{L}^{-1} \mathrm{BA}^{-1}$ $2 \mathrm{mg} \mathrm{L}^{-1}$ NAA after 40-45 days of culture Arrows: stylar canal. (e, f) Histological images of shoot primordia in the presence of $5 \mathrm{mg} \mathrm{L}^{-1} \mathrm{NAA}$ and $1 \mathrm{mg} \mathrm{L}^{-1} \mathrm{BA}, 40$-day-old cultures. (g) Histological section of an embryogenic callus of $C$. banaticus (25-day-old culture grown on $5 \mathrm{mg} \mathrm{L}^{-1} \mathrm{NAA}$ and $1 \mathrm{mg} \mathrm{L}^{-1} \mathrm{BA}$ ) showing somatic embryos. ge- globular stage embryo; ce- cotyledonary stage embryo. Scalebars: $100 \mu \mathrm{m}(\mathrm{a}), 500 \mu \mathrm{m}(\mathrm{b}-\mathrm{g})$

in C. scepusiensis and C. banaticus, band 2 in C. scepusiensis only, bands 3-4 in C. banaticus only and band 5 was present in all cultures belonging to the "Verni" series (C. scepusiensis, C. tommasinianus and C. vittatus). As for pyrogallol POD, all cultures were characterized by a common unique activity band (Fig. $3 b$ ).

\section{DISCUSSION}

There are various culture conditions, including PGR content of media, for the successful induction and maintenance of Crocus tissue cultures. One of them - high PGR (especially auxin) - requirement was frequently described both for $C$. sativus and its wild relatives. This includes not only cultures initiated from explants of floral organs, but also for corm explants. For the induction of calli capable of plant regeneration, this rule should be taken into account (Bhagyalakshmi, 1999; Plessner and Ziv, 1999; Demeter et al., 2010; Verma et al., 2016). Indeed, nearly all Crocus cultures involved in this study were initiated on a medium with $10 \mathrm{mg} \mathrm{L}^{-1}$ $\mathrm{NAA}$ and $1 \mathrm{mg} \mathrm{L}^{-1} \mathrm{BA}$. When the formation and stable subculture of such calli is established, different strategies/culture conditions are available for the induction of shoot or whole plant regeneration in the genus Crocus (see Plessner and Ziv, 1999; Karamian and Ebrahimzadeh, 2001; Ascough et al., 2009 for reviews of cultures for $C$. sativus and wild relatives). These culture conditions involve mainly somatic embryogenesis and include cultures initiated from corm explants: (i) decrease of PGR content in culture media together with changing of auxin/cytokinin ratio in favor of cytokinins and decrease of medium strength (Karamian, 2007; Demeter et al., 2010; Karamian and Ebrahimzadeh, 2010); (ii) high cytokinin content of media, with or without the use of auxin(s) (this strategy was used mainly for C. sativus and can be used for micropropagation purposes as well, where callus induction is not involved. It works well with both corm and shoot tip explants and can lead to cormlet formation, too - Devi et al., 2014); (iii) high organic carbon source (sucrose) content (up to $8 \%$ ) with or without the use of IBA was reported to promote rooting of regenerated Crocus shoots and cormlet formation (Sharma et al., 2008; Verma et al., 2016). Besides, cormlet development in Crocus tissue cultures occurs under various PGR treatments. Several papers report the importance of IBA (Zeybek et al., 2012), while others underline the use of 


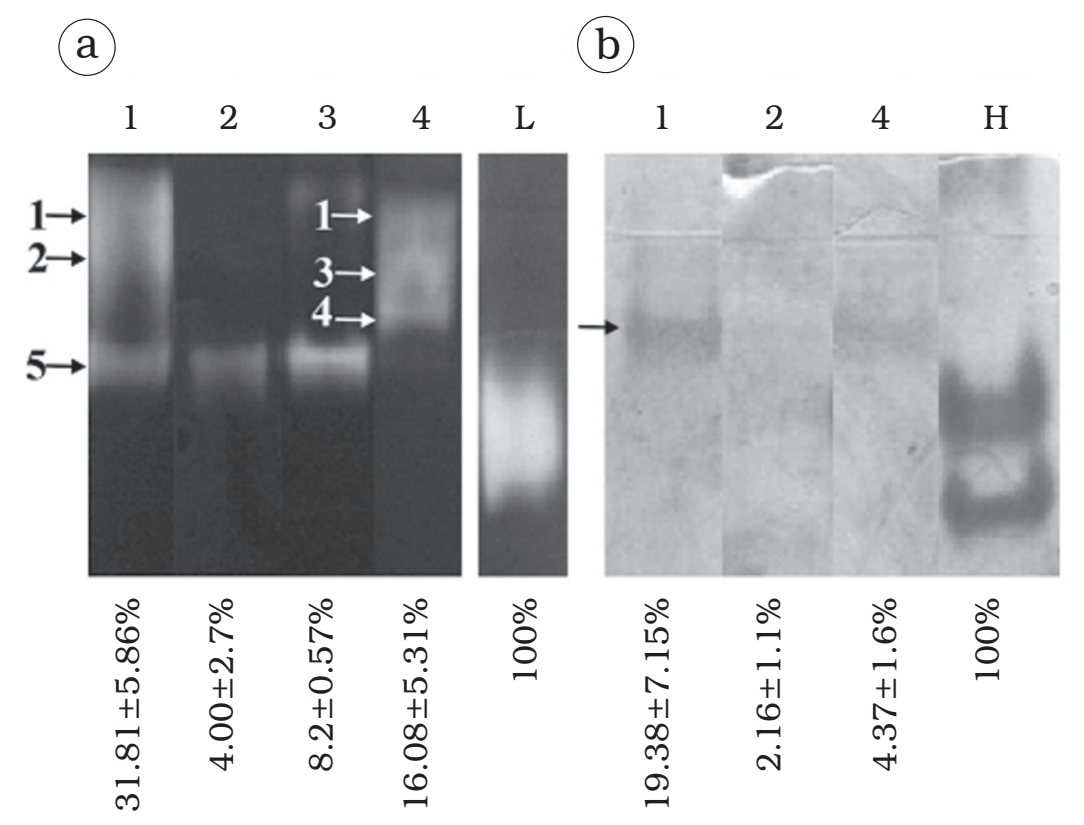

Fig. 3. Catalase (a) and pyrogallol peroxidase (b) activities of Crocus tissue cultures grown for 45 days on 5 mg L $\mathrm{L}^{-1} \mathrm{NAA}$ plus $1 \mathrm{mg} \mathrm{L}^{-1} \mathrm{BA}$ (except C. vittatus, cultured for 65 days on $10 \mathrm{mg} \mathrm{L}^{-1}$ NAA plus $1 \mathrm{mg} \mathrm{L}^{-1}$ BA). Activity gels were used for the assay. Lane $1-C$. scepusiensis; $2-C$. tommasinianus; $3-C$. vittatus; $4-C$. banaticus. Below gel images, mean $\pm \mathrm{SE}$ values of enzyme activities (expressed as band intensities) are shown. These values are the percentage of activities for positive controls known for high enzyme activities: Lemna whole plant extract (L) for catalase and horseradish root extract $(\mathrm{H})$ for pyrogallol peroxidase, $100 \%$ values. C. vittatus peroxidase activity ( $8.33 \pm 0.57 \%$ of positive control) is not shown in Fig. 3b. Arrows and numbers (numbers on the catalase gels only) indicate characteristic activity bands.

cytokinins without IBA (Sharma et al., 2008) for C. sativus. The use of high sucrose concentration and high cytokinin/auxin ratios was proven to be beneficial for plant regeneration and cormlet production from corm-derived somatic embryos in C. vernus (Sivanesan et al., 2012, 2014).

For the present study, concerning whole plant regeneration, culture condition (i) (as shown above, but without reducing medium strength) was used for C. tommasinianus and C. banaticus. Culture condition (ii) was the most efficient for C. scepusiensis, where organogenesis instead of embryogenesis occurred (however, for this species, SLSs were also formed under such conditions). Culture condition (iii) involving the use of IBA was used for $C$. tommasinianus, $C$. vittatus and $C$. banaticus. Efficient shoot or whole plant regeneration could be achieved for all Crocus species involved (Figs. 1-2 and Table 1).

Plant regeneration from somatic embryos requires particular PGR content in culture media. It is possible that under certain culture conditions somatic embryos show unipolar development with the differentiation of shoots only in Crocus and bipolar embryo development occurs only at welldefined PGR combinations (Blazquez et al., 2009). This phenomenon could be observed for two of our cultures showing somatic embryogenesis (C. tommasinianus and $C$. banaticus). The best example is $C$. banaticus, where for most PGR combinations studied, somatic embryos developed shoots. However, when auxin content was decreased, while cytokinin increased dramatically, whole plants with simultaneous shoot, root and cormlet differentiation occurred (Fig. $2 \mathrm{~h}$ ).

Concerning SLS formation, there are various PGR combinations inducing this type of morphogenesis. The explant type is also important (Plessner and Ziv, 1999). High cytokinin content favored SLS development, when half-ovary explants of $C$. sativus were used (Loskutov et al., 1999). Several studies report that high cytokinin and auxin content (higher than $4.5 \mu \mathrm{M}$ ) in media favor SLS formation from floral explants (see, e.g., Ebrahimzadeh et al., 2000). It should be noted that the above statements are valid only for C. sativus flower organs, while for corm explants there is a limited number of studies reporting SLS formation (Gantait and Vahedi, 2015). In the light of this, it is of particular interest that we could obtain SLS from corm explants in C. scepusiensis. It is worth mentioning here, that the anatomy of SLSs formed under tissue culture conditions (Figs. 2b-d) shows the general histological characteristics of 
native Crocus stigmas as reported by WeryszkoChmielewska and Chwil (2011), except that stigmatal papillae are absent in SLSs.

In C. sativus, different stages of development of callus structures capable of further shoot or whole plant regeneration are accompanied by specific changes in the pattern of antioxidant activity of enzymes like superoxide dismutase (SOD) or CAT (Blazquez et al., 2009). In this study we demonstrate that the isoenzyme pattern of CAT depends on the type of callus developed during tissue culture. Even though C. scepusiensis, C. tommasinianus and C. vittatus taxonomically belong to the same group (series Verni), morphogenetic events shown by C. scepusiensis cultures were clearly distinct from the other " $C$. vernus" species in that they were organogenic. Meanwhile, they were characterized by two additional CAT activity bands and showed higher (yet still low, as compared to the positive controls) CAT and POD activities, as compared to C. tommasinianus and C. vittatus (Fig. 3). C. banaticus had low antioxidant enzyme activity, as compared to C. scepusiensis. Meanwhile although taxonomical analysis is beyond the scope of this paper - with respect to CAT isoenzyme pattern, cultures of $C$. banaticus were distinct from all other three species involved in the present tissue culture studies (Fig. 3b), confirming that the species is evolutionarily distinct from species belonging to the "Verni" section (see, e.g., DNA fingerprinting studies of Mosolygó et al., 2016). Although CAT/POD isoenzyme patterns can vary between different tissues in the same plant, the patterns of tissue cultures were identical to the leaves of the corresponding native plants at least for $C$. tommasinianus and C. vittatus, where plant materials collected from the field (1-2 leaves) were available (Supplementary Fig. S1).

In conclusion, we established novel tissue cultures of four wild, rare/endangered Crocus species. Since all of them are capable of whole plant regeneration, they have a germplasm preservation value. $C$. vittatus and $C$. banaticus cultures produced cormlets on plant regeneration media (Table 1). These underground modified organs are suitable for ex vitro acclimatization, increasing their species conservation value (Gantait and Vahedi, 2015). The distinct callus types (organogenic vs. embryogenic) and taxonomical differences were reflected by differences in CAT activity patterns.

What could be the biotechnological importance of the present study? Apocarotenoids produced in many types of saffron tissue cultures are not applicable here, because wild relatives of saffron are not likely to efficiently produce apocarotenoids in their SLSs produced in vitro.
However, the in vitro SLS production strategy for C. scepusiensis presented in the Results section (Table 1) could be beneficial for those who are interested in the production of SLS in C. sativus in order to efficiently produce the characteristic saffron apocarotenoids. Moreover, corm-derived Crocus cultures have the potential of producing compounds with cytostatic (potential antitumor) properties, such as proteoglycans (Escribano et al., 1999; Fernández, 2006; Sharifi and Ebrahimzadeh, 2010).

\section{AUTHORS' CONTRIBUTIONS}

C.F. and S.A.P. made essential tissue culture and activity gel electrophoresis work. They also helped in the design of culture conditions. Z.D., Á.S. contributed to the initiation of tissue cultures, A.R. helped in the preparation and analysis of activity gels. A.M. and G.S. made the collection of plant samples from the field and their cultivation in the Botanical Garden of the University of Debrecen. C.M. designed experiments and wrote the manuscript.

\section{ACKNOWLEDGEMENTS}

This work was supported by internal University grants for C.F., Z.D. and A.R. (Universitas Foundation, 2013) and the TÁMOP-4.2.2/B-10/1-2010-0024 project for S.P. The authors would like to thank Claudia Kovács and Kristóf Szabó for their help in tissue culture work.

\section{REFERENCES}

Ascough GD, ERwin JE, and van Staden J. 2009. Micropropagation of Iridaceae - a review. Plant Cell, Tissue and Organ Culture 97: 1-19.

BHAGYALAKSHMI N. 1999. Factors influencing direct shoot regeneration from ovary explants of saffron. Plant Cell, Tissue and Organ Culture 58: 205-211.

Blazguez S, Olmos E, Hernández JA, Fernández-Garcia N, Fernandez JA, and Pigueras A. 2009. Somatic embryogenesis in saffron (Crocus sativus L.). Histological differentiation and implication of some components of the antioxidant enzymatic system. Plant Cell, Tissue and Organ Culture 97: 49-57.

BRADFORD MM. 1976. A rapid and sensitive method for the quantitation of microgram quantities of protein utilizing the principle of protein-dye binding. Analytical Biochemistry 72: 248-254.

Demeter $Z$, Surányi G, Molnár VA, Sramkó G, Beyer D, Kónya Z, Vasas G, M-Hamvas M, and Máthé C. 2010. Somatic embryogenesis and regeneration from shoot primordia 
of Crocus heuffelianus. Plant Cell, Tissue and Organ Culture 100: 349-353.

Demeter Z, Kanalas P, Máthé C, Cseke K, SzÖllösi E, M-HamVAS M, JÁMBRIK K, KISS Z, and MÉsZÁros I. 2014. Osmotic stress responses of individual white oak (Quercus section, Quercus subgenus) genotypes cultured in vitro. Journal of Plant Physiology 171: 16-24.

Devi K, Sharma M, and AhuJa PS. 2014. Direct somatic embryogenesis with high frequency plantlet regeneration and successive cormlet production in saffron (Crocus sativus L.). South African Journal of Botany 93: 207-216.

EBRAHIMZADEH H, RAGJABIAN T, and KaRAMian R. 2000. In vitro production of floral buds and stigma-like structures on floral organs of Crocus sativus L. Pakistan Journal of Botany 32: 141-150.

Escribano J, Rios I, and FERNÁNDEZ JA. 1999. Isolation and cytotoxic properties of a novel glycoconjugate from corms of saffron plant (Crocus sativus L.). Biochimica et Biophysica Acta 1426: 217-222.

FERNÁNDEZ JA. 2006. Anticancer properties of saffron, Crocus sativus Linn. In: Khan MTH, Ather A (Eds.) Lead molecules from natural products, 313-30. Elsevier, Amsterdam, The Netherlands.

Fernández JA, Santana O, and Guardiola JL et al. 2011. The world saffron and Crocus collection: strategies for establishment, management, characterisation and utilisation. Genetic Resources and Crop Evolution 58: 125-137.

Gamborg OL, Miller RA, and OJima K. 1968. Nutrient requirements of suspension cultures of soybean root cells. Experimental Cell Research 50: 151-158.

Gantait S, and VAhEDI M. 2015. In vitro regeneration of high value spice Crocus sativus L.: a concise appraisal. Journal of Applied Research on Medicinal and Aromatic Plants 2: 124-133.

Garda T, Kónya Z, Tándor I, Beyer D, Vasas G, Erdödi F, Vereb G, Papp G, Riba M, M-Hamvas M, and Máthé C. 2016. Microcystin-LR induces mitotic spindle assembly disorders in Vicia faba by protein phosphatase inhibition and not reactive oxygen species induction. Journal of Plant Physiology 199: 1-11.

KARAMIAN R. 2007. Somatic embryogenesis and plant regeneration from protoplast culture of Crocus pallasii subsp. hausknechtii. Pakistan Journal of Biological Sciences 10: 659-663.

KARAmian R, and EBRAhimZadeh H. 2001. Plantlet regeneration from protoplast-derived embryogenic calli of Crocus cancellatus. Plant Cell, Tissue and Organ Culture 65: $115-121$.

Karamian R, and Ebrahimzadeh H. 2010. Study on changes in protein patterns and phenolic contents during somatic embryogenesis in Crocus sativus L. Acta Horticulturae 850: 117-119.

KIRÁlY G, Ed. 2007. A magyarországi edényes flóra veszélyeztetett fajai/ Red list of the vascular flora in Hungary. Lővér Print, 13-50. Sopron, Hungary (in Hungarian, abstract available in English).
Loskutov AV, Beninger CW, Ball TM, Hosfield GL, Nair M, and SinKA C. 1999. Optimization of in vitro conditions for stigma-like-structure production from half-ovary explants of Crocus sativus L. In vitro Cellular and Developmental Biology- Plant 35: 200-205.

Máthé C, Demeter Z, Resetár A, Gonda S, Balázs A, SzőKe É, Kiss Z, Simon Á, Székely V, Riba M, Garda T, Gere B, NoSZÁly Z, MolnáR VA, and VASAS G. 2012. The plant tissue culture collection at Department of Botany, University of Debrecen. Acta Biologica Szegediensis 56: 179-182.

Mosolygó-L Á, Sramkó G, Barabás S, Czeglédi L, Jávor A, Molnár VA, and SuránYi G. 2016. Molecular genetic evidence for allotetraploid speciation in the genus Crocus L. (Iridaceae). Phytotaxa 258: 121-136.

Murashige T, and Skoog F. 1962. A revised medium for rapid growth and bioassays with tobacco tissue cultures. Physiologia Plantarum 15: 473-497.

PĂtroescu M, and RozyŁowicz L. 2000. Natural transborder parks: the direction of biodiversity preservation in Romania. In: Crabbé $\mathrm{P}$ et al. (eds) Implementing ecological integrity restoring regional and global environmental and human health, 101-113. Kluwer Acad. Publ., The Netherlands.

Plessner O, and ZIV M. 1999. In vitro propagation and secondary metabolite production in Crocus sativus L. In: Negbi M (ed) Medicinal and aromatic plants - industrial profiles, 137-148. Harwood Academic Publishers, Amsterdam, The Netherlands.

Sharifi G, and EBrahimzadeh H. 2010. Changes of antioxidant enzyme, activities and isoenzyme profiles during in vitro shoot formation in saffron (Crocus sativus L.). Acta Biologica Hungarica 61: 73-89.

SHARma KD, Rathour R, SHARMa R, Goel S, Sharma TR, and SinGH BM. 2008. In vitro cormlet development in Crocus sativus. Biologia Plantarum 52: 709-712.

SivANESAN I, Son MS, JANA S, and JEONG BR. 2012. Secondary somatic embryogenesis in Crocus vernus (L.) Hill. Propagation of Ornamental Plants 12: 163-170.

SivANESAN I, JANA S, and JEONG BR. 2014. In vitro shoot regeneration and microcorm development in Crocus vernus (L.) Hill. Pakistan Journal of Botany 46: 693-697.

Verma SK, DAS AK, Cingoz GS, Uslu E, and Gurel E. 2016. Influence of nutrient media on callus induction, somatic embryogenesis and plant regeneration in selected Turkish crocus species. Biotechnology Reports 10: 66-74.

WEIDERT CJ, and CULLEN JJ. 2010. Measurement of superoxide dismutase, catalase and glutathione peroxidase in cultured cells and tissue. Nature Protocols 5: 51-66.

Weryszko-Chmielewska E, and Chwil M. 2011. Structure of the floral parts of Crocus vernus (L.) Hill. Acta Agrobotanica 64: 35-46.

ZeYBeK E, ÖNDE S, and KAYA Z. 2012. Improved in vitro micropropagation methods with adventitious corms and roots for endangered saffron. Central European Journal of Biology 7: 138-145. 